Article

\title{
Governing the City of Flows: How Urban Metabolism Approaches May Strengthen Accountability in Strategic Planning
}

\author{
Cathrin Zengerling \\ Urban Footprints Research Group, HafenCity University Hamburg, 20457 Hamburg, Germany; \\ E-Mail: cathrin.zengerling@hcu-hamburg.de
}

Submitted: 21 September 2018 | Accepted: 28 January 2019 | Published: 21 February 2019

\begin{abstract}
The article aims to provide an initial insight into if and how urban metabolism perspectives and approaches may strengthen accountability in urban environmental strategic planning. It argues that many of the challenges in governing urban environmental flows successfully result from accountability gaps in strategic planning. The aim of the research is to test the assumption that urban metabolism perspectives and approaches strengthen accountability in urban environmental strategic planning. Applying a four-pillar accountability analysis to the strategic climate and resource plans of New York and Zurich, two cities which put environmental sustainability high on their political agenda, the study traces the role of urban metabolism perspectives and approaches and discusses the benefits these may have for accountable strategic planning with a focus on carbon and material flows. The interim results show on the one hand that implicit urban metabolism approaches are vital for both cities' strategic planning and that they contribute to strengthened accountability in all four pillars of the analysis: responsibility, transparency, assessment and participation. On the other hand, the analysis highlights further potential benefits of urban metabolism perspectives and approaches in urban strategic climate and resource planning.
\end{abstract}

\section{Keywords}

accountability; carbon flows; material flows; strategic planning; sustainable cities; urban governance; urban metabolism

\section{Issue}

This article is part of the issue "The City of Flows: Urban Planning of Environmental Flows", edited by Rob Roggema (Cittaideale, The Netherlands/Hanze University Groningen, The Netherlands).

(C) 2019 by the author; licensee Cogitatio (Lisbon, Portugal). This article is licensed under a Creative Commons Attribution 4.0 International License (CC BY).

\section{Introduction}

Cities are becoming increasingly engaged and recognized actors in multi-level and polycentric environmental governance. They develop and strive to implement environmental sustainability strategies, join transnational municipal networks (TMNs) and become visible in the institutional architecture of multilateral environmental agreements (MEAs) such as the Paris Agreement and the Convention on Biological Diversity. For example, more and more cities report climate targets in collaboration with TMNs via the transparency platform of the Non-State Actor Zone for Climate Action (NAZCA) established under the Paris regime. Some countries also explicitly include cities' mitigation and adaptation efforts in their Nationally Determined Contributions (NDCs). Due to their 'en- vironmental weight', cities are among the crucial actors in environmental governance. Research by the International Resource Panel has shown that in 2010 cities consumed about $75 \%$ of global energy and material flows (IRP, 2013) and that urban material consumption is expected to more than double from 40 billion tons in 2010 to approximately 90 billion tons in 2050 (IRP, 2018). Recognizing this key role, international political mandates, such as the Sustainable Development Goals and the New Urban Agenda, task cities to work towards (environmentally) sustainable urban systems. With this growing political importance of cities in environmental governance, there is also a growing body of research, especially in the field of urban climate governance (Bai et al., 2018; Bansard, Pattberg, \& Widerberg, 2017; Bulkeley et al., 2011; Heidrich et al., 2016; Heikkinen, Ylä-Anttila, \& 
Juhola, 2018; Reckien et al., 2014, 2018; see also Urban Knowledge-Action Network of Future Earth, n.d.).

This article builds on the initial insights of work in progress under an interdisciplinary research project at the intersection between law, urban planning and environmental sciences, focusing on the accountable governance of cities' carbon and material flows. It argues that many of the challenges in governing urban environmental flows successfully are based on accountability gaps in strategic planning and implementation and aims to identify ways to strengthen accountability. The research is based on the hypothesis that an urban metabolism perspective is helpful in strengthening accountability in urban environmental strategic planning. The aim of this article is to provide an insight into if and how urban metabolism perspectives and approaches are-explicitly or implicitly-instrumental in strengthening accountability in urban environmental strategic planning in the cities of New York and Zurich. It thereby intends to contribute to the puzzle of how to link urban metabolism and policy (Bai, 2016, p. 827; Dijst et al., 2018, p. 201). Section 2 below introduces the methodological approach of this interim study. Section 3 defines the basic terms and concepts of the research and introduces the four pillars of the accountability analysis. Section 4 applies the accountability analysis to climate and resource governance in the cities of New York and Zurich and traces the role of urban metabolism perspectives and approaches. Sections 5 and 6 discuss key findings and draw initial conclusions respectively.

\section{Methodology}

The methodological approach of this study is both conceptual and empirical. Conceptually, the study inserts urban strategic environmental planning and urban metabolism approaches into the wider context of accountable (urban) environmental governance. As an analytical framework the study applies an accountability analysis which has been developed in prior research and is explained in greater detail below (Section 3.2). The aim of the present study is to gain insights into how 'the city of flows' can be accountably governed internally via strategic environmental planning. The aim of the larger research project, which this study is part of, goes beyond this internal perspective. It traces accountability chains and their instrumental design not only within cities but also externally in cities' connections in multi-level and polycentric environmental governance structures (see Section 3.2 and Figure 1). Strategic plans are an important instrumental interface for internal and external relations because they steer and coordinate cities' efforts in the governance of environmental flows.

Empirically, the qualitative study applies the accountability analysis to key strategic environmental plans and related policy documents in the two case studies of New York and Zurich. With regard to New York, the analysis focuses mainly on the sustainability section of the current plan OneNYC; in the case of Zurich it examines the Roadmap 2000-Watt-Society as well as the 2050 Resource Strategy. The study examines in the context of each pillar of the accountability analysis-responsibility, transparency, assessment and participation-if and how urban metabolism perspectives and approaches, as presented in Section 3.3, have been used explicitly or implicitly in strengthening accountability in such plans (Sections 4 and 5). In addition, the study also draws on related scientific and grey literature. It is important to note that this methodology can only produce interim results of work in progress. In the further course of the research it will be extended and deepened conceptually as well as empirically, inter alia via interviews and the collection of local data.

\section{Governing the City of Flows: Definitions and Conceptual Approaches}

The following subsections introduce the understanding of environmental governance and strategic planning as used in this study, the methodological approach of the accountability analysis and the concept of urban metabolism.

\subsection{Urban Environmental Governance, Strategic Planning and Modes of Governance}

The term governance is applied in this study as defined by the Commission on Global Governance in its fundamental report Our Global Neighborhood. Accordingly:

Governance is the sum of the many ways individuals and institutions, public and private, manage their common affairs. It is a continuing process through which conflicting or diverse interests may be accommodated and co-operative action may be taken. It includes formal institutions and regimes empowered to enforce compliance, as well as informal arrangements that people and institutions either have agreed to or perceive to be in their interest. (Carlsson, Ramphal, Alatas, \& Dahlgren, 1995)

Environmental governance refers to governance activities concerned with the common matter of the environment. Consequently, urban environmental governance encompasses city-led initiatives such as, for example, municipal climate action planning or waste recycling schemes, as well as neighborhood cooperatives, multiurban bodies developing an integrated transport plan with user groups or regional initiatives of state agencies, industries and residents, for example, to control deforestation (cf. Carlsson et al., 1995).

This study is written from a global north perspective and focuses on urban environmental strategic planning. The quality of such overarching strategic plans, such as, for example, the OneNYC plan, is one crucial factor in the success or failure of a city's ambitions to reach certain de- 
velopment goals. As those tools may cover many flows in the city, such as energy, water, waste, traffic, green infrastructure, materials, etc., they are an important place to identify and deal with systemic changes, areas and measures which need integrative planning and areas of synergy and conflict. The strategic plans may contain procedural and substantive rules which require or enable future cross-sectoral communication, coordination and integrated decision-making. They may also set up new institutional bodies empowered and staffed to facilitate such tasks. Another important success factor for strategic plans is appropriate budgeting. Tasks may only be completed if the necessary staff and measures can be financed. From a procedural point of view, adaptive management cycles enable a periodic assessment and review of past measures and achievements and eventually adjustment of strategic plans.

A strategic plan usually establishes targets and a management framework to ensure that the targets are reached. However, before specific measures are implemented, the broader rules of the strategic plan need to be fleshed out and translated into formal and informal instruments which actually bring about specific changes in urban land use, infrastructures or activities. At this point, sectoral administrations, plans and instruments come into play and may hinder or facilitate changes as envisaged by the overarching strategic plan (see Jones, 2016). Institutional, procedural and substantive rules which require continuous communication, coordination and joint decision-making may increase the chance of the need for systemic, integrative, synergistic and conflict-sensitive detailed planning and implementation not to get lost in sectoral routines and power structures. The process of developing a strategic plan and the design of specific measures can be crucial for the success of its implementation. If relevant actors, including sectoral administrations, private businesses and citizens, participate in the process and co-shape plans and measures responsive to their needs and capacities, it becomes much more likely that the envisaged changes become reality (with a focus on knowledge building see Sara \& Baud, 2014).

When designing strategic plans, urban planners and policy-makers may establish measures in six modes of governance as identified in the extensive research into city-level action on climate change by Bulkeley et al. (2011): self-governance, provision, regulation, enabling, partnership and experimentation (see also Bulkeley \& Castán Broto, 2013; Bulkeley \& Kern, 2006, p. 2242; Bulkeley et al., 2011, p. 8). This comprehensive approach to clustering municipal scope for action may also be transferred to the broader field of urban environmental strategic planning. Self-governance refers to the power of municipalities to govern their own activities; provision addresses municipalities' influence on the provision of certain services and resources; regulation encompasses local law-making and planning law and thus basic instruments of exerting local authority; enabling captures municipalities' opportunities to support, coor- dinate and incentivize activities with or of private businesses, NGOs, local communities and citizens; local governments may cooperate with other stakeholders via partnerships (Bulkeley \& Kern, 2006, p. 2242; Bulkeley et al., 2011, p. 8); finally, municipalities may use experimental interventions to reconfigure socio-technical systems (Bulkeley \& Castán Broto, 2013).

Procedural and substantive legal requirements for strategic planning may vary significantly depending on each country's legal framework. However, in many cases instruments of strategic planning are either 'informal', in the sense that there is no law prescribing the procedure or (limited) content of the planning tool or formalized but not strictly limited in content. Thus, very frequently, a local government may choose to include measures from all six modes of local governance mentioned above in their strategic planning. This opens a wide scope of action for urban environmental strategic planning and enables the local government to steer and coordinate city-wide efforts in the governance of environmental flows towards reaching agreed environmental targets.

\subsection{Accountability (Gaps) in Three Perspectives of Environmental Governance}

SDG 16 and the New Urban Agenda contain political mandates for accountable (urban) governance. However, they do not define what accountability actually means. In layman's terms, accountability is defined as "the quality or state of being accountable ( = answerable, explainable); especially: an obligation or willingness to accept responsibility or to account for one's actions" (Accountability, n.d.). In the theory of representative democracy, accountability plays a crucial role in the context of the exercise of state authority and the so-called principal-agent paradigm. In this traditional view, the principal is the citizens and mechanisms of accountability ensure that the exercise and delegation of power to state-agents takes place according to the principal's will (see Biermann \& Gupta, 2011; Shah \& Shah, 2006; Zengerling, 2018). A growing body of research, especially in the field of political science, grapples with the concept of accountability. For example, Biermann and Gupta (2011) identified four essential elements of accountability: (1) a normative element defined as a certain standard of behavior, (2) a relational element linking principal and agent, (3) a decision element in the form of a judgment about whether the standard of behavior has been met, and (4) a behavioral element that allows deviant behavior to be sanctioned. Chan and Pattberg (2008) define accountability more broadly as a "more or less coherent set of rules and procedures, delineating who takes part in decisionmaking, who holds whom responsible for what kind of actions, and by which means".

In a system of polycentric environmental governance-which emphasizes the diversified structure of actors in different forms of networks and focuses on bottom-up rather than top-down initiatives (Dorsch \& 
Flachsland, 2017; Jordan et al., 2015) -accountability becomes more complex than defined in the traditional view of representative democracy (Widerberg \& Pattberg, 2017). There is a wider range of principals and agents (Bäckstrand, Zelli, \& Schleifer, 2018, p. 344). For example, cities as actors in polycentric climate governance regulate themselves but are also regulated. They do not only function in a vertical system of state hierarchy but also horizontally, for example as members of TMNs (Bäckstrand et al., 2018, p. 344). Therefore, the accountability analysis of the overall research project aims to trace accountability chains and their instrumental design in three different perspectives: vertically (relationships between cities, states and MEAs), horizontally (relationships between cities, e.g., via TMNs), and internally (focusing on cities' internal strategic environmental planning; see Figure 1).

The present study focusses on the internal perspective of urban environmental strategic planning. Reacting to empirical findings that indicate accountability gaps in cities' climate action planning, it aims to trace internal accountability chains and accountability design. Despite empirical research on urban climate governance in Europe which showed efforts in target setting and strategic climate action (Heidrich et al., 2016; Reckien et al., 2014), there is still little evidence as to whether this actually led to GHG emission reductions (van der Heijden, 2018). Instead, research identified a lack of mechanisms that ensure that targets are met (Bulkeley et al., 2011; Sippel, 2011) and an "accountability vacuum" (Bache, Bartle, Flinders, \& Marsden, 2015; see also Bäckstrand et al., 2018). Empirical research focusing on the role of TMNs suggests that membership has not so far fostered reliable implementation and monitoring procedures (Bansard et al., 2017) or transformational change (Heikkinen et al., 2018). The lack of local data (Bai et al., 2018) and standardized accounting in urban GHG inventories also makes it difficult to assess the effective- ness of cities' climate action planning (Dahal \& Niemelä, 2017; Yetano Roche et al., 2014; see also Wang, Engels, \& Wang, 2017; Zengerling, 2018). With regard to material flows, empirical studies show a trend towards increasing resource use and material inefficiency on a global scale (Chávez et al., 2018, p. 85). However, due to lack of local data it is difficult to assess the part played by cities in this trend (Chávez et al., 2018, p. 85).

Prior research in this project identified four pillars of accountability drawing on political mandates, scientific literature and mechanisms established under the Paris regime: responsibility, transparency, assessment, and participation (Zengerling, 2018, pp. 148-149). The following paragraphs describe each pillar in greater detail and highlight the associated accountability gaps in urban environmental strategic planning. Responsibility covers who is responsible to whom, for what kinds of actions (e.g., emission reductions), by which means (e.g., monitoring and reporting, submitting to compliance control), and in which forms (e.g., voluntary, intended, or mandatory). The internal responsibility of a city government to reach certain environmental goals depends on the formal or informal nature of an environmental strategic plan. In most cases environmental strategic plans are informal plans, which means that they are not legally binding for other actors. This constitutes an important accountability gap which can be mitigated, for example, by ensuring that targets and measures in the strategic plan are implemented via formal sectoral or detailed plans. Another option to alleviate this challenge is to adopt clear and detailed targets connected to a transparent assessment which allows for public scrutiny. Furthermore, implementation of an informal strategic plan in the absence of enforcement powers becomes more likely if it is based on a broad societal consensus and contains economic or social incentives.

Transparency refers to who needs to communicate to whom, what kind of information (e.g., current emissions,

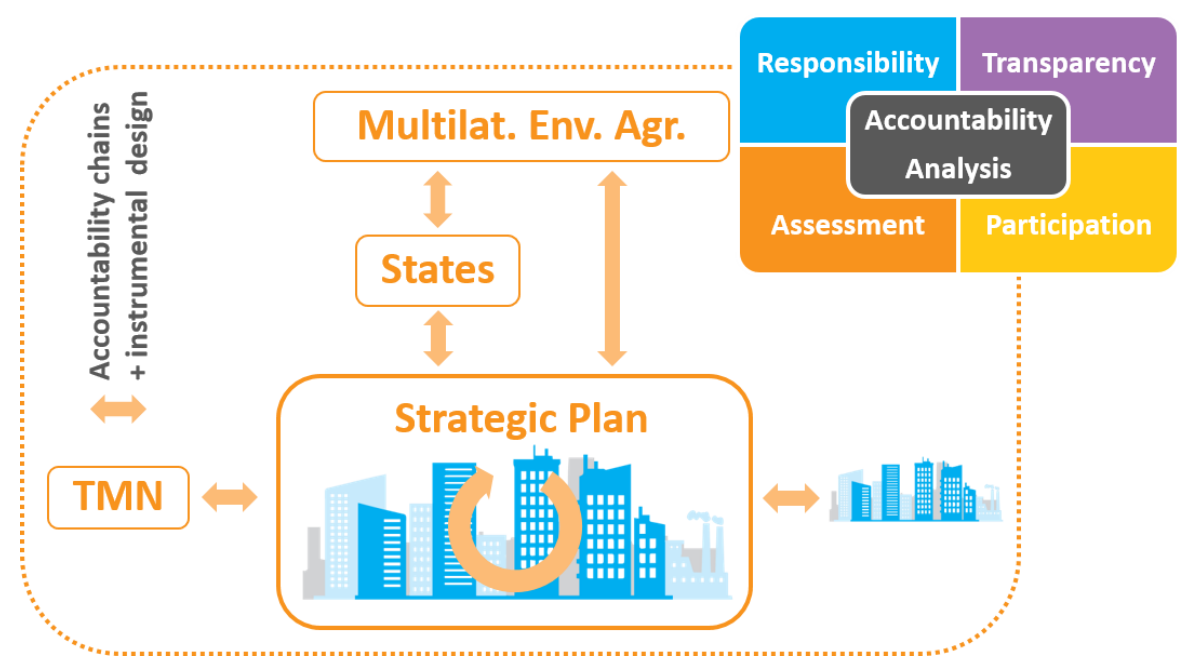

Figure 1. Framework of accountability analysis in multi-level and polycentric governance system Source: Zengerling and Gionatan Vignola (graphic design). 
strategies, or costs) and in which form (e.g., publicly available or disclosed only to certain actors). Transparent governance of the city of flows would e.g., encompass transparency portals which make a wide range of information on the city's environmental flows publicly available. Key accountability gaps with regard to transparency in strategic planning are the lack of local data, shortcomings in the quality of data, and limited disclosure of data.

Assessment encompasses collection, measurement, verification, evaluation and modeling of data relating to an agreed goal, choice and application of methodologies and evaluation schemes (Zengerling, 2018, p. 149; see also Jones, 2016). Among the key accountability gaps with a view to assessment in strategic planning are the lack of local data, methodologically sound and comparable inventories, or indicators. As stated above, cities' GHG inventories use a variety of different methodologies and data and are generally not comparable (Dahal \& Niemelä, 2017; Yetano Roche et al., 2014). Usually, cities apply some form of production-based accounting. The vast majority of current urban GHG inventories result from the chosen methodologies and use, in the absence of local data, of national data not appropriate for informing local decision-making or assessing progress at local level. A joint initiative of the World Resources Institute, C40 Cities and ICLEI developed the Global Protocol for Community-Scale GHG Emission Inventories (GPC). It is based on the IPCC methodology and offers a framework to account for not only scope 1 but also scope 2 and 3 emissions. Member cities of C40 and ICLEl are encouraged to apply this framework. Kennedy, one of the researchers involved in developing the GPC, applied the methodology to his comparative study on 22 global cities' infrastructure emissions (Kennedy, Ibrahim, \& Hoornweg, 2014). Increasingly, scientists are developing methodologies for consumptionbased accounting and transboundary footprinting at city level (Pichler et al., 2017; Wheeler, Jones, \& Kammen, 2018; see also Creutzig et al., 2018). It is important not to mix methodologies because this would lead to doublecounting (Wheeler et al., 2018, p. 37).

Participation refers to involvement of different actors in decision-making processes. Participating parties may be representatives of other sectors of the administration, private businesses, NGOs, groups of or individual citizens. There are different forms and stages of participation, ranging from direct to indirect and from information, consultation, involvement and cooperation up to empowerment. Forms of participation may also differ along the steps of a policy cycle from goal setting, choice of instruments and implementation to evaluation and adjustment. In many procedural rules of formal planning instruments, only parties affected by a certain plan or policy have a legal right to participate. However, planners and other administrative representatives in charge of decision-making are usually free to go beyond such legal minimum requirements. With respect to informal instruments, such as most strategic environmental plans, the decision-maker is free to design participatory processes. Thus, accountability gaps in strategic planning with a view to participation are often the limited scope and quality of participation.

\subsection{Urban Metabolism Perspectives and Approaches}

Looking at a city as a city of flows is directly linked to the concept of urban metabolism. It has been developed by Wolman (1965) and, according to Kennedy, Pincetl and Bunje (2010), may be defined as "the sum total of the technical and socio-economic processes that occur in cities, resulting in growth, production of energy, and elimination of waste". Urban metabolism studies involve "'big picture' quantification of the inputs, outputs and storage of energy, water, nutrients, materials, wastes for an urban region" (Kennedy et al., 2010). The International Resource Panel frames urban metabolism as "a lens through which cities can be studied in order to understand major resource and energy flows, and identify infrastructural investments that would enable cities to shift from a linear (i.e., wasteful) metabolism to a resource-efficient metabolism" (IRP, 2013, 2018). A wider and more human-centered perspective elaborated by Currie and Musango (2017) understands the urban metabolism as the "collection of complex sociotechnical and socio-ecological processes by which flows of materials, energy, people, and information shape the city, service the needs of its populace, and impact the surrounding hinterland". Bai (2016) and Chávez et al. (2018) developed and used similarly wide concepts of urban metabolism. Figure 2 aims to visualize the urban metabolism framework in the context of accountable strategic planning.

Comprehensive studies of urban metabolism exist for a still small but growing number of cities (Kennedy, 2016; Kennedy et al., 2010). For example, Rosado, Niza and Ferrão (2014) developed an urban metabolism analyst (UMAn) model and studied material flows from 2003 to 2009 disaggregated into 28 material types, 55 economic activity categories and their spatial location for the Lisbon metropolitan area in 2014. The study was also related to the cities' strategic planning in waste management and could be used as an accompanying projection and assessment tool for informed local decision-making (Rosado et al., 2014). In an international study Kennedy et al. (2015) quantified energy and material flows for 27 megacities and established correlations for electricity consumption, heating and industrial fuel use, ground transportation energy use, water consumption, waste generation, and steel production in terms of heatingdegree-days, urban form, economic activity, and population growth. However, it is important to note that those studies are not only based on local data but also still apply extrapolations of national statistical data.

In their UNEP report Urban Metabolism for Resource Efficient Cities, Musango et al. (2017) summarize the key approaches for assessing the urban metabolism: ac- 


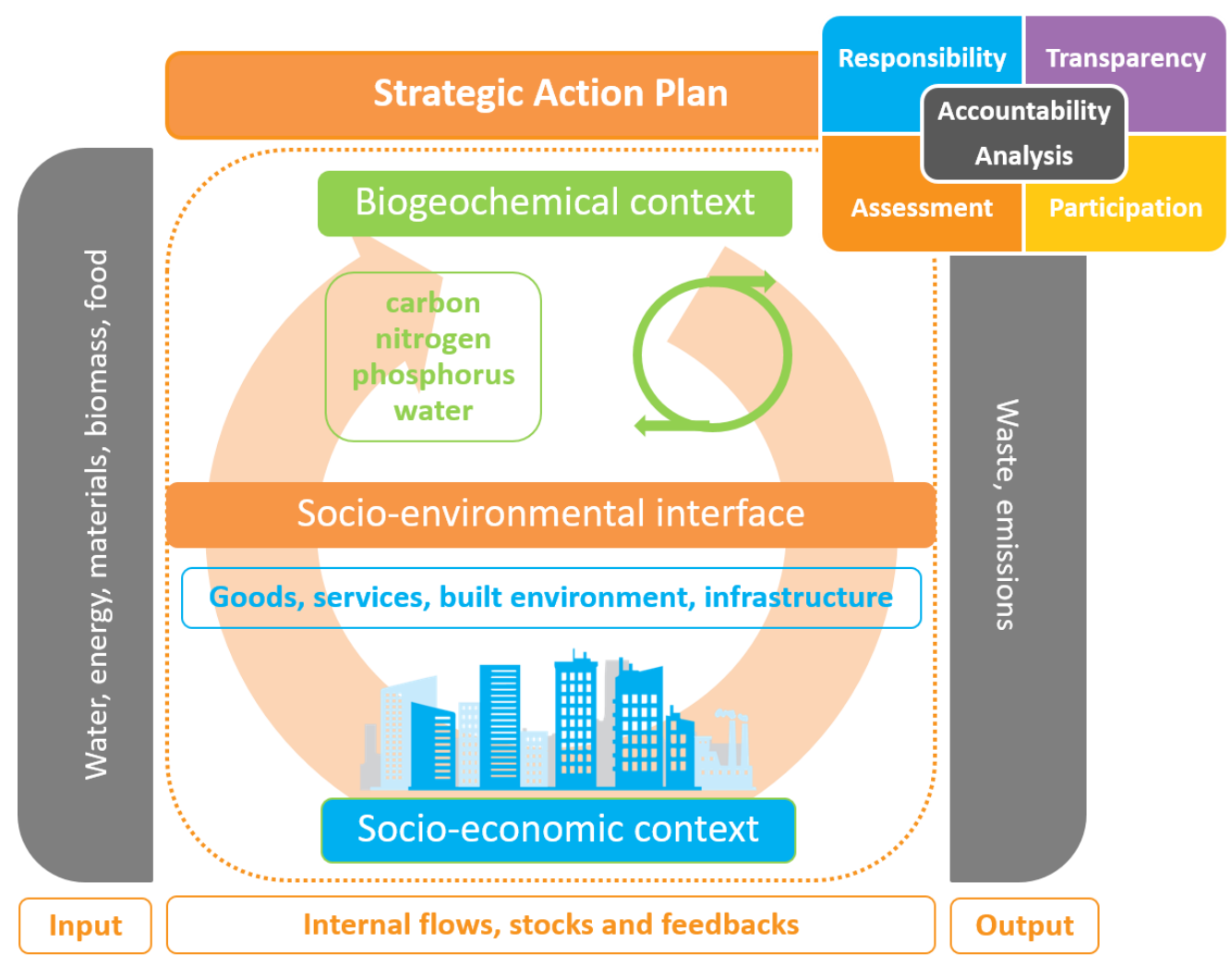

Figure 2. Urban metabolism framework and accountable strategic planning. Source: Zengerling and Gionatan Vignola (graphic design), drawing on Ferrão and Fernández (2013) and Musango, Currie and Robinson (2017).

counting approaches such as material and substance flow analysis, input-output analysis, ecological footprint analysis, life cycle assessment, simulation methods, as well as hybrid methods combining and extending the traditional methods. The report also maps and lists 165 urban metabolism case studies and the approaches used respectively (Musango et al., 2017, pp. 15, 28). In their recent article on urban metabolism and interdisciplinary perspectives Dijst et al. (2018) include a non-exhaustive table on urban metabolism approaches, which encompasses the approaches mentioned by Musango et al. (2017) but goes into greater detail, especially with respect to efficiency, health and socio-economic indicators (Dijst et al., 2018, p. 199). As Kennedy pointed out, there are several fields of application of urban metabolism studies within urban sustainability transitions: urban metabolism research may contribute to developing and following-up on urban sustainability indicators, it may contribute to urban GHG accounting, develop dynamic mathematical models for policy analysis and it may be used as a design tool for urban planning (Kennedy et al., 2010). With such fields of application, urban metabolism studies have great potential to contribute to strengthening accountability in the four fields outlined above. If and how the cities of New York and Zurich use urban metabolism perspectives and approaches in their key strategic plans in the fields of climate and resource governance is explored and discussed in the following two sections.

\section{Accountability Analysis of Strategic Planning in New York and Zurich: First Insights}

The following case studies explore city-led strategic planning of carbon and material flows in the cities of New York and Zurich through the lens of the four pillars of the accountability analysis.

\subsection{New York City}

The City of New York has ambitious goals. It strives to be "the most sustainable big city in the world and a global leader in the fight against climate change" (OneNYC, 2015, pp. 6, 160). In 2007, the mayor at the time, Michael Bloomberg, embarked on this journey and enacted the PlaNYC as the key strategic plan in working towards these goals. Building on these prior efforts, in 2015, Mayor Bill de Blasio issued a new strategic plan: the One New York: The Plan for a Strong and Just City (OneNYC, 2015). The 354-page document formulates visions, goals, targets, indicators and initiatives in four fields and respective subthemes: urban growth (covering, inter alia, industry, workforce, housing and transportation); justice and equity (capturing health, social service and criminal justice); sustainability (encompassing GHG emission reduction, clean air and water, zero waste, and green infrastructures) and resilience (dealing with neighborhoods, buildings, infrastructure and coasts). The appendix contains a relatively comprehensive table on initiatives and 
a total of $\mathbf{4 7}$ more or less specific supporting initiatives within each subtheme, the lead agency in charge, as well as status and source of the required funding (OneNYC, 2015, p. 266).

A first review of the sustainability section of OneNYC shows elements of accountability in all four pillars. The City of New York assumes a political (not a legally binding) responsibility towards its citizens for reaching specific reduction goals. The key overarching goals of the sustainability section with regard to carbon and material flows are a reduction of $80 \%$ in the cities' GHG emissions by 2050 and a $90 \%$ reduction in disposed waste by 2030 , both relative to 2005 . The GHG reduction goal has been reinforced and turned into an administratively binding goal by Executive Order 26 passed by Mayor de Blasio in June 2017 and planned for in more detail under the strategic $1.5^{\circ} \mathrm{C}$ : Aligning New York City with the Paris Climate Agreement plan (henceforth called the NYC Climate Action Plan), issued in September 2017. The GHG emission reduction target is fleshed out via four initiatives targeting specific emission reductions in the power, transport, waste and building sectors (OneNYC, 2015, pp. 168-174). Each initiative consists of several specific measures, with a lead agency in charge, funding status and milestones (OneNYC, 2015). Similarly, the OneNYC plan establishes eight initiatives to reach its waste reduction target in the fields of the organics and curbside recycling program, reduction of plastic bags, citizen involvement in reduction and recycling, zero waste schools, reuse and recycling of textiles and electronic waste, a save-as-you-throw program, and reduction of commercial waste (OneNYC, 2015, pp. 178-187).

As far as transparency is concerned, the OneNYC plan is written in accessible language, clearly structured and contains relatively comprehensive tables of goals, initiatives, measures, responsibilities, funding status, milestones and indicators (OneNYC, 2015, pp. 166187). Concrete budgets are not mentioned in the plan. Strategic plans and progress reports are publicly available (OneNYC, 2018). The City of New York has an open data portal (opendata.cityofnewyork.us) with information on several sectors of environmental quality, including energy consumption, GHG emissions and waste management.

The City of New York publishes annual indicatorbased progress reports (OneNYC, 2018). Progress under the GHG emission reduction goal is assessed via two inventories as required under Local Law 22 of 2008 (NYC Climate Action Plan, 2017, Appendix III): a city-wide GHG inventory and a city government GHG inventory. The city-wide GHG inventory applies the methodology of the Global Protocol for Cities (NYC Climate Action Plan, 2017, p. 42). It shows a $15 \%$ reduction in the city-wide annual GHG emissions from 2005 to 2016 (NYC Climate Action Plan, 2017, p. 43). Compared to 2015, GHG emissions remained flat. According to the explanatory notes, the reduction was achieved despite significant increases in population and economic activity. Interestingly, the
City of New York strives also to account in future for consumption-based emissions in addition to the GPC methodology (NYC Climate Action Plan, 2017, p. 44). This will be an important step towards capturing the contribution of the city's infrastructures and lifestyles to climate change in a more holistic manner (Pichler et al., 2017; Wheeler et al., 2018). Depending on the findings, it will also allow the city to widen the range of reduction activities on the political agenda accordingly. Progress under the waste reduction goal is measured via three indicators. With regard to the volume of DSNY-collected refuse, the 2018 progress report shows a decline in comparison to the 2005 baseline, but a slight increase compared to 2016 (OneNYC, 2018, p. 64). The second indicator is a curbside and containerized diversion rate. It increased slightly from $16.9 \%$ in 2016 to $17.4 \%$ in 2017 (OneNYC, 2018 , p. 64). Regarding the third indicator, citywide diversion rate-covering all waste streams: residential, commercial, construction and demolition, and fill-the report refers to a lack of available data (OneNYC, 2018, p. 64).

Research on participation in the planning process of PlaNYC highlights strengths and weaknesses. On the one hand, Mayor Bloomberg created-alongside the City's Office of Long-Term Planning and Sustainability-a 16person Sustainability Advisory Committee with representatives from businesses, consultancy, NGOs and community activists (Rosan, 2011, p. 966). Many advocacy groups and individuals commented on the plan and Town Hall meetings were hosted in every borough (Rosan, 2011, p. 967). However, critics argue that participation was not meaningful in the sense of joint development of PlaNYC. They highlight that the plan already existed, and the purpose of participatory activities was rather to sell the idea than to shape it (Angotti, 2008; Rosan, 2011, p. 966). In this context it is interesting to note that neither PlaNYC nor OneNYC went through an approval procedure under Section 197 of the New York Charter (Angotti, 2008, p. 5; Rosan, 2011, p. 966). An evaluation from an environmental justice perspective points to several positive procedural and substantive aspects of PlaNYC but identifies room for improvement (Rosan, 2011, p. 973). A study on the performance management system established under the Bloomberg administration for PlaNYC points to important progress in measuring mitigation activities, but also highlights a lack of community engagement (Jones, 2016, p. 753). Furthermore, it concludes that the managerial approach applied by the Bloomberg administration resulted in most NYC departments not adopting many PlaNYC objectives and significant deficits in support for and implementation of crossagency initiatives (Jones, 2016, pp. 752-753).

\subsection{Zurich}

The city of Zurich does not have an overarching urban development vision comparable to the OneNYC plan. In 2015, Zurich city council approved the mid-term strategic document Zurich Strategies 2035 under the slogan 
"Zurich-Sustainable today and tomorrow: a summary of challenges and objectives". The 36-page paper is-as the slogan says-more a summary than a strategic plan. It does not contain any specific targets or initiatives but links to more specific plans and policies in various fields. Nevertheless, the City of Zurich can be seen as a role model in governing its carbon and material flows. Via a community vote in 2008 , with $74 \%$ in favor, the citizens of Zurich signed up to the goal of becoming a "2000-Watt Society" (Art. 2ter from the Municipal Code) and reducing per capita $\mathrm{CO}_{2}$ emissions to $1 \mathrm{t} / \mathrm{y}$ by 2050 (Art. 122 from the Municipal Code). The current overarching policy document guiding this process is the Roadmap 2000Watt Society plan issued by the city council in November 2016. It encompasses 57 measures mostly at city and partly at Canton and national level in the sectors of consumption, settlement, buildings, energy supply and mobility (Stadt Zürich, 2016a). The Energy Master Plan, the Environment Master Plan and the Urban Traffic 2025 plan are the key sectoral strategic plans for reaching the envisaged goals. With regard to material flows, the city as well as the Zurich Canton are actively engaged in urban mining (AWEL, 2014a, 2014b; Stadt Zürich, 2009). For example, the percentage re-use of construction and demolition waste and use of recycled concrete is continuously being optimized. There are also initial industrial processes in place to recover phosphorus from waste water streams (AWEL, 2018).

Elements of all four pillars of accountability can be found in Zurich's strategic plans. With regard to responsibility, it is interesting to note that-unlike the City of New York-the key targets of the 2000-Watt Society are part of the city's Municipal Code and thus legally binding. The roadmap identifies specific areas of action and specific ongoing, planned and further measures in the sectors of consumption, buildings, energy supply, mobility, and settlement (Stadt Zürich, 2016a). The Energy Master Plan formulates reduction targets for primary energy and GHG emissions for the years 2020, 2035 and 2050 based on 2005 levels with regard to the city as a whole and the city's administration. In line with the overall 2000-Watt goal, targets for primary energy and GHG emission reduction are in addition set on a per capita basis (Stadt Zürich, 2016b, p. 11). In its 2050 Resource Strategy the City of Zurich developed a knowledge base, targets and strategies for efficient use and recycling of mineral building materials (Stadt Zürich, 2009). Targets and strategies in the 2050 Resource Strategy are based on an analysis of the city's material stocks and flows of buildings and physical infrastructure as well as the related energy demand. Based on modeling of urban material stocks and flows, the 2050 resource strategy developed three different scenarios up to the year 2050 and a dynamic modeling of the building stock, as well as best practices for the dismantling, disposal and recycling of construction waste (Stadt Zürich, 2009; see also AWEL, 2009). The strategic plans on the 2000-Watt Society and the 2050 resource strategy are fleshed out further via formal and informal plans and measures (Stadt Zürich, 2016b, p. 13, for energy).

With respect to transparency and assessment, the City of Zurich shows progress in achieving the goals of the 2000-Watt Society via an inventory of its consumption of primary energy and GHG emissions (Stadt Zürich, 2018). 2016 data indicates that the 2020 goal for GHG emission reduction is unlikely to be reached, whereas the 2020 goal for reduction in primary energy consumption is likely to be attained (Stadt Zürich, 2018). Zurich also issues a Statistics Yearbook. The 2017 issue, for instance, provides, inter alia, data on waste (chapter 7), primary energy consumption and GHG emissions (Stadt Zürich, 2017a, chapter 8). Furthermore, the city issues reports as a follow-up to its Master Plans on Energy and Environment (Stadt Zürich, 2017b, 2017c) which transparently show past developments and predictions in the areas of energy and material flows. With regard to consumptionbased accounting it is important to note that the inventories at city level do not account for grey energy - the embodied energy required to produce a product or servicein consumption. However, there is an inventory for individual consumers updated every 6 to 10 years which does account for grey energy in individual consumption based on national average data. With regard to material flows follow-up reports show the continuously optimized re-use of construction and demolition waste and use of recycled concrete.

In terms of participation it is noteworthy that the city's decision to transition to a 2000-Watt Society is based on $74 \%$ support in a referendum of Zurich citizens. The strategic plan Roadmap 2000-Watt Society has been developed by the city's department for health and environment with broad participation from other departments in Zurich's administration (Stadt Zürich, 2016a, p. 9). The 2050 Resource Strategy has also been developed within the city's administration with the main responsibilities lying with the departments for construction and engineering as well as health and environment (Stadt Zürich, 2009, p. 2).

\section{Do Urban Metabolism Perspectives and Approaches Strengthen Accountable Strategic Planning? First Insights}

Building on the conceptualizations and definitions of urban metabolism perspectives and approaches outlined in Section 3.3, this section examines whether and how the cities of New York and Zurich use them in their key strategic plans. To gain insights into whether they strengthen accountability in strategic planning, this section traces urban metabolism perspectives and approaches through the lens of the accountability analysis. More specifically, this section examines if and how the concept of urban metabolism as such and its accounting methods, such as material and substance flow analysis, input-output analysis, ecological footprint analysis, life cycle assessment, simulation methods, or a com- 
bination of these and the related generation of local data, are explicitly or implicitly used in strategic planning. In addition, the documents are scrutinized with respect to the use of environmental and socio-economic indicators, dynamic mathematical modeling and the use of urban metabolism as a design tool for urban planning. The focus remains on carbon and material flows, specifically GHG emission reduction efforts in both cities and-with regard to material flows - the zero-waste goal of New York and construction material and phosphorus recycling in Zurich. Figure 3 summarizes the use of urban metabolism perspectives and approaches in governing carbon and material flows in the cities of New York and Zurich within the four pillars of the accountability analysis. All areas of the table highlighted in dark and light green build on or directly use urban metabolism approaches as outlined above.

It is important to note that the concept of 'urban metabolism' was not explicitly mentioned in the plans and related documents examined. The clearest use of urban metabolism perspectives and approaches is in Zurich's 2050 Resource Strategy and its efforts in urban mining. Neither of the cities aimed to describe qualitatively, quantitatively or conceptually its urban metabolism either in a holistic manner as outlined above (Section 3.3, Figure 2) or with respect to specific fields, e.g., via relating biogeochemical flows, socio-economic context and the socio-environmental interfaces. Nevertheless, implicit urban metabolism approaches are used in both cities and for the benefit of accountability in strategic planning.

With respect to responsibility both cities use urban metabolism approaches to develop 2050 visions, targets, measures and indicators for governing their carbon and material flows. Both cities used dynamic mathematical models to predict and assess different policy scenarios in their efforts to reduce GHG emissions and work towards zero waste (New York) or improved recycling of construction materials and phosphorus (Zurich). Data on past, current and predicted future scenarios of the cities' carbon and material flows supported informed decision-making in target setting, choice of measures and indicators. It also plays a crucial role in identifying areas of synergy and conflict and the design of integrated solutions (e.g., synergies between energy and waste sectors for New York; see also Hoornweg, Sugar, \& Trejos Gómez, 2011).

\begin{tabular}{|c|c|c|c|c|}
\hline \multirow{2}{*}{$\begin{array}{l}\text { Env. } \\
\text { Flows } \\
\text { Cities }\end{array}$} & \multicolumn{2}{|c|}{ Carbon Flows } & \multicolumn{2}{|c|}{ Material Flows } \\
\hline & New York & Zurich & New York & Zurich \\
\hline $\begin{array}{ll}\frac{u}{\square} & \frac{n}{E} \\
\frac{\pi}{5} & \frac{\pi}{2}\end{array}$ & $\begin{array}{l}\text { OneNYC (sustainability chapter) } \\
\text { and related documents }\end{array}$ & $\begin{array}{l}\text { Roadmap } 2000-\text { Watt Society and } \\
\text { related documents }\end{array}$ & $\begin{array}{l}\text { OneNYC (sustainability chapter) } \\
\text { and related documents }\end{array}$ & $\begin{array}{l}2050 \text { Resource Strategy and } \\
\text { related documents }\end{array}$ \\
\hline \multirow[t]{2}{*}{ 气ू̆ } & - $\quad$ GHG emission reduction & - $\quad \mathrm{GHG}$ emission reduction & zero waste & $\begin{array}{l}\text { Recycling of construction } \\
\text { materials } \\
\text { Recycling of phosphorus }\end{array}$ \\
\hline & \multicolumn{4}{|c|}{ Urban metabolism perspectives and approaches } \\
\hline 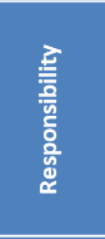 & $\begin{array}{l}\text { Visions, targets, goals, } \\
\text { initiatives, measures based } \\
\text { on inventories and } \\
\text { modeling } \\
-80 \% \text { target } \\
\text { - } \quad \text { Local Law } 22 \mathrm{GHG} \\
\text { inventory }\end{array}$ & $\begin{array}{l}\text { Visions, targets, measures } \\
\text { based on inventories and } \\
\text { modeling } \\
\text { 2000-Watt society } \\
\text { - } 1 \mathrm{t} / \mathrm{y} \text { target }\end{array}$ & $\begin{array}{l}\text { Visions, targets, goals, } \\
\text { initiatives, measures based } \\
\text { on inventories and } \\
\text { modeling } \\
-90 \% \text { target }\end{array}$ & $\begin{array}{l}\text { Visions, targets and } \\
\text { measures based on } \\
\text { inventories, MFAs, SFAs, } \\
\text { LCAs, and modeling } \\
\text { Several collection and } \\
\text { recycling quotas }\end{array}$ \\
\hline 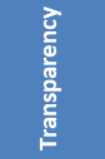 & $\begin{array}{l}\text { - } \quad \text { Public plans and progress } \\
\text { reports } \\
\text { - NYC Open Data }\end{array}$ & $\begin{array}{l}\text { - Public plans and progress } \\
\text { reports } \\
\text { - Statistics yearbook }\end{array}$ & $\begin{array}{l}\text { - } \quad \text { Public plans and progress } \\
\text { reports } \\
\text { - } \quad \text { NYC Open Data }\end{array}$ & $\begin{array}{l}\text { - } \quad \text { Public plans and progress } \\
\text { reports } \\
\text { - } \quad \text { Statistics yearbook }\end{array}$ \\
\hline 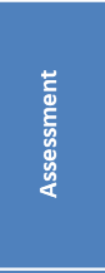 & $\begin{array}{ll}\text { - } & \text { Progress report } \\
\text { One indicator, four } \\
\text { initiatives } \\
\text { - } \quad \text { City-wide and city gov. GHG } \\
\text { inventory } \\
\text { - } \quad \text { PPC methodology } \\
\text { Planned: consumption- } \\
\text { based inventory }\end{array}$ & $\begin{array}{ll}\text { - } & \text { Progress reports } \\
\text { - } & \text { Indicators } \\
\text { - } & \text { GHG emission inventory } \\
\text { Primary energy } \\
\text { consumption inventory } \\
\text { - Inventory for individual } \\
\text { consumers }\end{array}$ & $\begin{array}{ll}- & \text { Progress report } \\
\text { - } & \text { Three indicators, eight } \\
\text { initiatives }\end{array}$ & $\begin{array}{ll}\text { - } & \text { Progress reports } \\
\text { - } & \text { Indicators } \\
\text { Inventories of material } \\
\text { stocks and flows } \\
\text { Dynamic modeling of } \\
\text { future material flows }\end{array}$ \\
\hline$\frac{\text { 을 }}{\frac{\mathrm{c}}{\mathrm{c}}}$ & $\begin{array}{ll}\text { - } & \text { Information and } \\
\text { - } & \text { consultation } \\
\text { - } & \text { Poft compliance control } \\
& \text { potannial: participatory }\end{array}$ & $\begin{array}{ll}\text { - } & \text { Information and } \\
\text { - } & \text { Consultation } \\
\text { - } & \text { Potential: participatory } \\
& \text { planning }\end{array}$ & $\begin{array}{ll}\text { - } & \text { Information and } \\
\text { - } & \text { Sonsultation } \\
\text { - } & \text { Potential: participatory } \\
& \text { planning }\end{array}$ & $\begin{array}{ll}\text { - } & \text { Information and } \\
\text { - } & \text { Sonsultation } \\
\text { - } & \text { Potential: participatory } \\
& \text { planning }\end{array}$ \\
\hline
\end{tabular}

Figure 3. Use of urban metabolism perspectives and approaches in governing carbon and material flows in the cities of New York and Zurich within the four pillars of the accountability analysis. 
Both cities publish strategic plans and follow-up reports. The use of urban metabolism approaches supports detailed display, reasoning and follow-up of visions, targets, measures, indicators and related data and thus overall transparency. Both cities publish past and current data on carbon and material flows in open data portals. There might be potential in future to integrate carbon and material flows also into open mapping portals of the cities (see NYCityMap, 2018).

New York and Zurich strongly draw on urban metabolism approaches with respect to assessment. Inventories of GHG emissions and material flows as well as the collection of data related to the chosen indicators are the basis for the continuing review of success and failures in the implementation of the measures outlined in the strategic plans. In the City of New York, the use of two types of GHG emission inventories is even required under Local Law 22 of 2008 (NYC Climate Action Plan, 2017, Appendix III): a city-wide GHG inventory and a city government GHG inventory. The city-wide GHG inventory applies the methodology of the Global Protocol for Cities (NYC Climate Action Plan, 2017, p. 42). Both cities strive to improve their scope and methodologies of accounting over time. For example, New York aims to track consumption-based GHG emissions in the future. Zurich constantly improves its material inventories.

Finally, urban metabolism approaches contribute to the quality of participation. For example, the transparent and detailed strategic plans of both cities as well as information provided in open data portals and in progress reports enhance the quality of information to citizens and the potential for soft compliance control. At the same time the data gathered in such strategic planning processes may contribute to meaningful consultation, cooperation and co-design of plans and measures on different spatial scales (Attia \& Khalil, 2015; Currie \& Musango, 2017). However, at this stage of the research it was not clear if urban metabolism perspectives and approaches have been used as a design tool in participatory planning.

To sum up, on the one hand the analysis shows that in both cities the use of urban metabolism approaches in strategic plans and related documents strengthens accountability in all four pillars. On the other hand, the review highlights that neither Zurich nor New York explicitly mention urban metabolism as a concept in their strategic planning. This might be due to the fact that the concept of 'urban metabolism' has so far mainly been developed and applied in academic research. However, this also indicates that more holistic urban metabolism perspectives, that connect biogeochemical and socio-economic contexts via a socio-environmental interface, are not yet used to their full potential in the strategic plans. Perhaps the development of flow charts which connect quantitative environmental flows with specific socio-economic actors and also consider and ideally visualize spatial dimensions could be a first step towards informing strategic planning via a socio-environmental-spatial perspective. To strengthen the socio-environmental interface it might also be important to extend the 'classic' toolbox of urban metabolism approaches as outlined in Section 3.3 by approaches used in the social sciences (see also Dijst et al., 2018).

\section{Conclusions}

Cities are becoming increasingly important actors in multi-level and polycentric environmental governance. However, empirical research has not so far been able to establish that cities reach their environmental targets. On the contrary, it identified a lack of mechanisms that ensure that targets are met. The article argued that many of the challenges in governing urban environmental flows successfully are the result of accountability gaps in strategic planning. It assumed that urban metabolism perspectives and approaches may strengthen accountability. The objective of the research was to test this assumption and gain initial insights into if and how urban metabolism perspectives and approaches are-explicitly or implicitly-instrumental in strengthening accountability in strategic climate and resource planning in the cities of New York and Zurich.

The analysis showed that implicit urban metabolism approaches are vital for both cities' strategic planning and that they contribute to strengthened accountability in all four pillars of the analysis: responsibility, transparency, assessment and participation. However, it also revealed that neither New York nor Zurich explicitly uses the concept of urban metabolism in their strategic plans. There was also no evidence that cities' strategic planning drew on the holistic urban metabolism perspective encompassing biogeochemical and socio-economic contexts connected via a socio-environmental interface.

Based on these interim results of work in progress, three conclusions may be drawn. Firstly, urban metabolism approaches strengthen accountability in strategic environmental planning. Secondly, there is currently unused potential in holistic urban metabolism perspectives encompassing socio-economic and socioenvironmental aspects to further enhance accountable urban environmental strategic planning. Thirdly, urban metabolism researchers might need to extend the toolbox of urban metabolism approaches to better capture the holistic perspective and make it easier for practitioners to draw on it.

\section{Acknowledgments}

This research is supported by a Volkswagen Foundation Freigeist Fellowship. The author also thanks the two anonymous reviewers of an earlier draft for their valuable comments.

\section{Conflict of Interests}

The author declares no conflict of interests. 


\section{References}

Accountability. (n.d.). In Merriam Webster dictionary. Retrieved from www.merriam-webster.com/ dictionary/accountability

Angotti, T. (2008). Is New York's sustainability plan sustainable? Paper presented at the joint ACSP/AESOP Conference, Chicago. Retrieved from www.hunter. cuny.edu/ccpd/repository/files/is-nycs-sustainability -plan-sustainable.pdf

Attia, S., \& Khalil, H. A. E. (2015). Urban metabolism and quality of life in informal areas. In Proceedings REAL CORP 2015: Plan together-right now-overall. Proceedings of 20th international conference on urban planning, regional development and information society (pp. 661-674). The Hague: CORP-Competence Center of Urban and Regional Planning.

AWEL. (2009). Rohstoff- und Aushubflüsse im Kanton Zürich-Ein dynamisches Modell der Materialflüsse für die Jahre 1995-2025 (Final Report) [Flows of raw and excavated materials in the Canton of Zurich-A dynamic model of material flows for the years 19952025 (author's translation)]. Zurich: AWEL. Retrieved from awel.zh.ch/internet/baudirektion/awel/de/ abfall_rohstoffe_altlasten/veroeffentlichungen/_jcr_ content/contentPar/publication_2/publicationitems/ rohstoff_und_aushubf/download.spooler.download. 1320053283413.pdf/rohstoff_aushubfluesse_kanton _zuerich_schlussbericht_2009.pdf

AWEL. (2014a). Urban mining potential: Factsheets. Amt für Abfall, Wasser, Energie und Luft. Retrieved from awel.zh.ch/internet/baudirektion/awel/de/abfall_ rohstoffe_altlasten/rohstoffe/urban_mining_poten tialbetrachtung.html

AWEL. (2014b). Maßnahmenplan der Abfall- und Ressourcenwirtschaft 2015-2018 [Action plan for waste and resource management 2015-2018 (author's translation]. Amt für Abfall, Wasser, Energie und Luft. Retrieved from awel.zh.ch/internet/ baudirektion/awel/de/abfall_rohstoffe_altlasten/ab fallplanung_2015_2018.html

AWEL. (2018). Phosphor Mining-Die Umsetzung des Phosphor Mining bedingt Kooperation (Phos4Life Project no 6). [Phosphor Mining: The implementation of phosphor mining requires cooperation (author's translation)]. Zürich: AWEL. Retrieved from zar-ch.ch/fileadmin/user_upload/Contentdokumente/ Phosphor/projektblatt_phosphor_klaerschlammasche nn_6.pdf

Bache, I., Bartle, I., Flinders, M., \& Marsden, G. (2015). Blame games and climate change: Accountability, multi-level governance and carbon management. The British Journal of Politics \& International Relations, 17(1), 64-88.

Bäckstrand, K., Zelli, F., \& Schleifer, P. (2018). Legitimacy and accountability in polycentric climate governance. In A. Jordan (Ed.), Governing climate change. Polycentricity in action (pp. 338-356). Cambridge: Cam- bridge University Press.

Bai, X. (2016). Eight energy and material flow characteristics of urban ecosystems. Ambio, 45, 819-830.

Bai, X., Dawson, R. J., Ürge-Vorsatz, D., Delgado, G. C., Barau, A. S., Dhakal, S., . . . Schultz, S. (2018). Six research priorities for cities and climate change. $\mathrm{Na}$ ture, 555(7694), 23-25.

Bansard, J. S., Pattberg, P. H., \& Widerberg, O. (2017). Cities to the rescue? Assessing the performance of transnational municipal networks in global climate governance. International Environmental Agreements: Politics, Law and Economics, 17(2), 229-246.

Biermann, F., \& Gupta, A. (2011). Accountability and legitimacy in earth system governance: A research framework. Ecological Economics, 70(11), 1856-1864.

Bulkeley, H., \& Castán Broto, V. (2013). Government by experiment? Global cities and the governing of climate change. Transactions of the Institute of British Geographers, 38(3), 361-375.

Bulkeley, H., \& Kern, K. (2006). Local government and the governing of climate change in Germany and the UK. Urban Studies, 43(12), 2237-2259.

Bulkeley, H., Schroeder, H., Janda, K., Zhao, J., Armstrong, A., Chu, S. Y., \& Ghosh, S. (2011). The role of institutions, governance, and urban planning for mitigation and adaptation. Paper prepared at the World Bank Urban Symposium on Climate Change. Durham and Oxford: Department of Geography, Durham University, and Environmental Change Institute, University of Oxford. Retrieved from siteresources.worldbank. org/INTURBANDEVELOPMENT/Resources/336387-125 6566800920/6505269-1268260567624/Bulkeley.pdf

Carlsson, I., Ramphal, S., Alatas, A., \& Dahlgren, H. (1995). Our global neighbourhood: The report of the commission on global governance. Oxford: Oxford University Press.

Chan, S., \& Pattberg, P. (2008). Private rule-making and the politics of accountability: Analyzing global forest governance. Global Environmental Politics, 8(3), 103-121.

Chávez, A., Kennedy, C., Chen, B., Chertow, M., Baynes, T., Chen, S., \& Bai, X. (2018). Understanding, implementing, and tracking urban metabolism is key to urban futures. In T. Elmqvist, X. Bai, N. Frantzeskaki, C. Griffith, D. Maddox, T. McPhearson, ... M. Watkins, (Eds.), The urban planet: Knowledge towards sustainable cities (pp. 68-91). Cambridge: Cambridge University Press.

Creutzig, F., Roy, J., Lamb, W. F., Azevedo, I. M., de Bruin, W. B., Dalkmann, H., . . . Hertwich, E. G. (2018). Towards demand-side solutions for mitigating climate change. Nature Climate Change, 8(4), 268.

Currie, P. K., \& Musango, J. K. (2017). African urbanization: Assimilating urban metabolism into sustainability discourse and practice. Journal of Industrial Ecology, 21(5), 1262-1276. 
Dahal, K., \& Niemelä, J. (2017). Cities' greenhouse gas accounting methods: A study of Helsinki, Stockholm, and Copenhagen. Climate, 5(2), 31.

Dijst, M., Worrell, E., Böcker, L., Brunner, P., Davoudi, S., Geertman, S., . . . Lenz, B. (2018). Exploring urban metabolism: Towards an interdisciplinary perspective. Resources, Conservation and Recycling, 132, 190-203.

Dorsch, M. J., \& Flachsland, C. (2017). A polycentric approach to global climate governance. Global Environmental Politics, 17(2), 45-64.

Ferrão, P., \& Fernández, J. E. (2013). Sustainable urban metabolism. Boston: MIT press.

Urban Knowledge-Action Network of Future Earth. (n.d.). List of publications. Future Earth. Retrieved from www.futureearth.org/urban-knowledge-action-net work-publications

Heidrich, O., Reckien, D., Olazabal, M., Foley, A., Salvia, M., de Gregorio Hurtado, S., . . Hamann, J. P. (2016). National climate policies across Europe and their impacts on cities strategies. Journal of Environmental Management, 168, 36-45.

Heikkinen, M., Ylä-Anttila, T., \& Juhola, S. (2018). Incremental, reformistic or transformational: What kind of change do C40 cities advocate to deal with climate change? Journal of Environmental Policy \& Planning, 21(1), 1-14.

Hoornweg, D., Sugar, L., \& Trejos Gómez, C. L. (2011). Cities and greenhouse gas emissions: Moving forward. Environment and Urbanization, 23(1), 207-227.

IRP. (2013). City-level decoupling: Urban resource flows and the governance of infrastructure transitions (Working Group on Cities of the International Resource Panel Report). Nairobi: United Nations.

IRP. (2018). The weight of cities: Resource requirements of future urbanization (Working Group on Cities of the International Resource Panel Report). Nairobi: United Nations.

Jones, S. (2016). 'If you can make it here, you can make it anywhere': Performance management and PlaNYC climate change initiatives. Regional Studies, 50(4), 744-755.

Jordan, A. J., Huitema, D., Hildné, M., van Asselt, H., Rayner, T. J., Schoenefeld, J. J., . . . Boasson, E. L. (2015). Emergence of polycentric climate governance and its future prospects. Nature Climate Change, 5, 977-982.

Kennedy, C. A., Pincetl, S., \& Bunje, P. (2010). The study of urban metabolism and its applications to urban planning and design. Environmental Pollution, 159(8), 1965-1973.

Kennedy, C. A., Ibrahim, N., \& Hoornweg, D. (2014). Lowcarbon infrastructure strategies for cities. Nature Climate Change, 4(5), 343-347.

Kennedy, C. A., Stewart, I., Facchini, A., Cersosimo, I., Mele, R., Chen, B., .. . Dubeux, C. (2015). Energy and material flows of megacities. Proceedings of the $\mathrm{Na}$ - tional Academy of Sciences, 112(19), 5985-5990.

Kennedy, C. A. (2016). Industrial ecology and cities. In R. Clift \& A. Druckman (Eds.), Taking stock of industrial ecology (pp. 69-86). Berlin: Springer.

Musango, J. K., Currie, P., \& Robinson, B. (2017). Urban metabolism for resource efficient cities: From theory to implementation. Paris: United Nations. Retrieved from resourceefficientcities.org/wp-content/ uploads/2017/09/Urban-Metabolism-for-ResourceEfficient-Cities.pdf

NYC Climate Action Plan. (2017). $1.5^{\circ} \mathrm{C}$ : Aligning New York City with the Paris Climate Agreement. New York City Government. Retrieved from www1.nyc.gov/ site/sustainability/codes/1.5-climate-action-plan.page

NYCityMap. (2018). Maps. New York City Government. Retrieved from maps.nyc.gov/doitt/nycitymap

OneNYC. (2015). One New York City: The plan for a strong and just city. The City of New York. Retrieved from onenyc.cityofnewyork.us

OneNYC. (2018). One NYC progress report. The City of New York. Retrieved from onenyc.cityofnewyork.us/ wp-content/uploads/2018/05/OneNYC_Progress_ 2018.pdf

Pichler, P. P., Zwickel, T., Chavez, A., Kretschmer, T., Seddon, J., \& Weisz, H. (2017). Reducing urban greenhouse gas footprints. Scientific Reports, 7(1), 14659.

Reckien, D., Flacke, J., Dawson, R. J., Heidrich, O., Olazabal, M., Foley, A., . . . Geneletti, D. (2014). Climate change response in Europe: What's the reality? Analysis of adaptation and mitigation plans from 200 urban areas in 11 countries. Climatic Change, 122(1/2), 331-340.

Reckien, D., Salvia, M., Heidrich, O., Church, J. M., Pietrapertosa, F., De Gregorio-Hurtado, S., . . Orru, H. (2018). How are cities planning to respond to climate change? Assessment of local climate plans from 885 cities in the EU-28. Journal of Cleaner Production, 191, 207-219.

Rosado, L., Niza, S., \& Ferrão, P. (2014). A material flow accounting case study of the Lisbon metropolitan area using the urban metabolism analyst model. Journal of Industrial Ecology, 18(1), 84-101.

Rosan, C. D. (2011). Can PlaNYC make New York City "greener and greater" for everyone? Sustainability planning and the promise of environmental justice. Local Environment, 17(9), 959-976.

Sara, M. L., \& Baud, I. S. A. (2014). Knowledge-building in adaptation management: Concertation processes in transforming Lima water and climate change governance. Environment and Urbanization, 26(2), 505-524.

Shah, A., \& Shah, S. (2006). The new vision of local governance and the evolving roles of governments. In A. Shah (Ed.), Local governance in developing countries (pp. 1-46). Washington, DC: The World Bank.

Sippel, M. (2011). Urban GHG inventories, target setting and mitigation achievements: How German cities fail to outperform their country. Greenhouse Gas Mea- 
surement and Management, 1(1), 55-63.

Stadt Zürich. (2009). Ressourcenstrategie "Bauwerk Stadt Zürich", Materialflüsse und Energiebedarf bis 2050 [Resource strategy "Building the City Zurich": Material flows and energy demand up to 2050 (author's translation)]. Stadt Zürich. Retrieved from www.energie-ressourcen.ch/Downloads/Ressourcen strategie_Stadt_Zuerich.pdf

Stadt Zürich. (2016a). Roadmap 2000-Watt-Society. Stadt Zürich. Retrieved from www.stadt-zuerich.ch/ gud/de/index/umwelt_energie/2000-watt-gesellscha ft.html\#

Stadt Zürich. (2016b). Energy master plan of the city of Zurich. Stadt Zürich. Retrieved from www.stadtzuerich.ch/content/dam/stzh/dib/Deutsch/Energie versorgung/Publikationen\%20und\%20Broschueren/ Masterplan_Energie_Englische_Version.pdf

Stadt Zürich. (2017a). Statistisches Jahrbuch [Statistical yearbook]. Retrieved from www.stadt-zuerich.ch/ jahrbuch

Stadt Zürich. (2017b). Bericht Energiepolitik 2015-2016 [Report on energy policy 2015-2016 (author's translation]. Stadt Zürich. Retrieved from www.stadtzuerich.ch/dib/de/index/energieversorgung/jahres bericht-energiepolitik.html

Stadt Zürich. (2017c). Umweltbericht [Environmental report (author's translation)]. Stadt Zürich. Retrieved from www.stadt-zuerich.ch/gud/de/index/ umwelt_energie/umweltbericht.html

Stadt Zürich. (2018). Hier steht die Stadt Zürich. [Status quo of the city of Zurich (author's translation)]. Stadt Zürich. Retrieved from www.stadt-zuerich.ch/gud/ de/index/umwelt_energie/2000-watt-gesellschaft/ auf-gutem-weg.html

Van der Heijden, J. (2018). City and subnational governance. High ambitions, innovative instruments and polycentric collaborations? In A. Jordan (Ed.), Governing climate change. Polycentricity in action (pp. 81-96). Cambridge: Cambridge University Press.

Wang, C., Engels, A., \& Wang, Z. (2017). Overview of research on China's transition to low-carbon development: The role of cities, technologies, industries and the energy system. Renewable and Sustainable Energy Reviews, 81, 1350-1364.

Wheeler, S. M., Jones, C. M., \& Kammen, D. M. (2018). Carbon footprint planning: Quantifying local and state mitigation opportunities for 700 California cities. Urban Planning, 3(2), 35-51.

Widerberg, O., \& Pattberg, P. (2017). Accountability challenges in the transnational regime complex for climate change. Review of Policy Research, 34(1), 68-87.

Wolman, A. (1965). The metabolism of cities. Scientific American, 213(3), 178-193.

Yetano Roche, M., Lechtenböhmer, S., Fischedick, M., Gröne, M. C., Xia, C., \& Dienst, C. (2014). Concepts and methodologies for measuring the sustainability of cities. Annual Review of Environment and Resources, 39, 519-547.

Zengerling, C. (2018). Action on climate change mitigation in German and Chinese cities. A search for emerging patterns of accountability. Habitat International, 75, 147-153.

\section{About the Author}

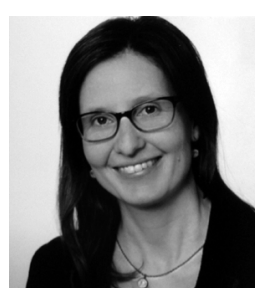

Cathrin Zengerling is head of the research group "Urban Footprints-Towards Greater Accountability in the Governance of Cities' Carbon and Material Flows" at HafenCity University Hamburg. She holds a PhD in international environmental law and specializes in (international) environmental, planning and energy law. Her current research focuses on urban climate and resource protection at the intersection of law, urban planning and environmental sciences. It is funded by a Volkswagen Foundation FreigeistFellowship. 